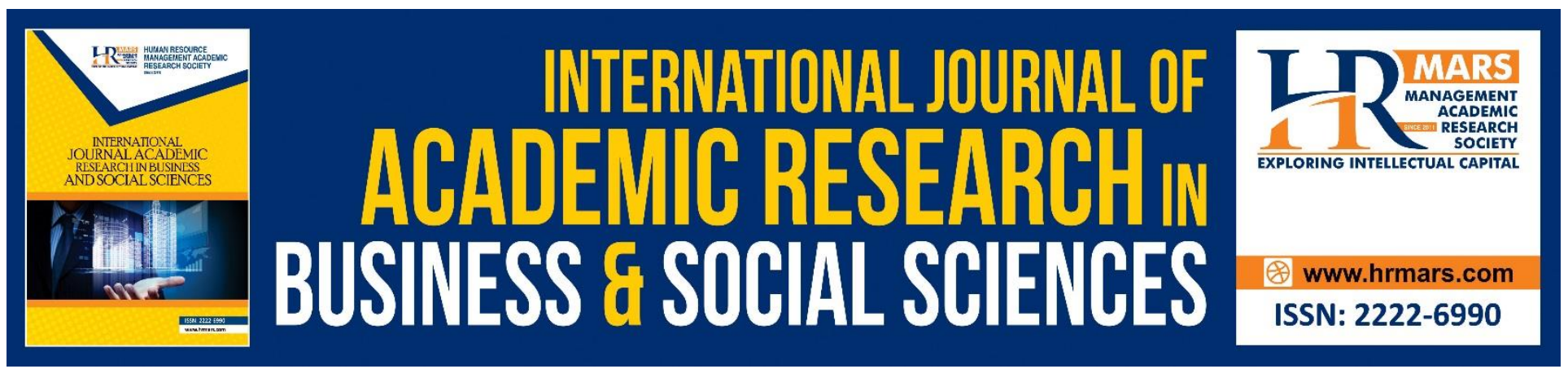

\title{
Measuring the Efficiency of Pan African Commercial Banks: An Application of Malmquist DEA Methods
}

\section{Abebe Bayu Cheriye}

To Link this Article: http://dx.doi.org/10.6007/IJARBSS/v10-i8/7665

DOI:10.6007/IJARBSS/v10-i8/7665

Received: 04 May 2020, Revised: 09 June 2020, Accepted: 14 July 2020

Published Online: 27 August 2020

In-Text Citation: (Cheriye, 2020)

To Cite this Article: Cheriye, A. B. (2020). Measuring the Efficiency of Pan African Commercial Banks: An Application of Malmquist DEA Methods. International Journal of Academic Research in Business and Social Sciences. 10(8), 942-954.

\section{Copyright: (C) 2020 The Author(s)}

Published by Human Resource Management Academic Research Society (www.hrmars.com)

This article is published under the Creative Commons Attribution (CC BY 4.0) license. Anyone may reproduce, distribute, translate and create derivative works of this article (for both commercial and non-commercial purposes), subject to full attribution to the original publication and authors. The full terms of this license may be seen

at: http://creativecommons.org/licences/by/4.0/legalcode

\section{Vol. 10, No. 8, 2020, Pg. 942 - 954}

Full Terms \& Conditions of access and use can be found at http://hrmars.com/index.php/pages/detail/publication-ethics 


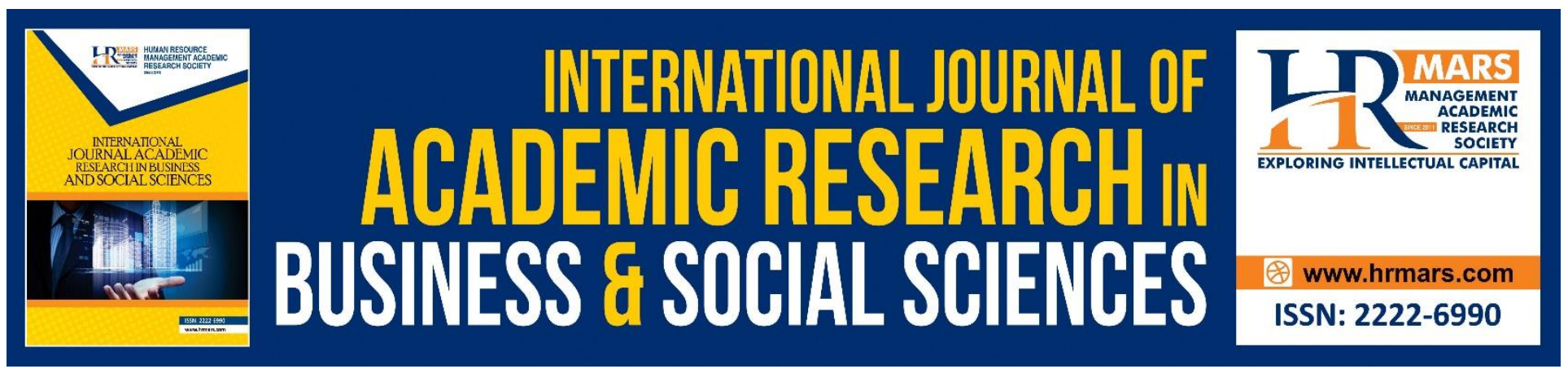

\title{
Measuring the Efficiency of Pan African Commercial Banks: An Application of Malmquist DEA Methods
}

\author{
Abebe Bayu Cheriye (PhD) \\ Kotebe Metropolitan University (KMU), Ethiopia \\ Email: drabebebayu@gmail.com
}

\begin{abstract}
This paper aims to measure the efficiency of Pan African Commercial Banks using Malmquist Data Envelopment Analysis Methods (DEA) over the period 2010-2015. Malmquist DEA methods are used to calculate indices of total factor productivity change; technological change; technical efficiency change and scale efficiency change. According to empirical findings, the total factor productivity of Pan African Commercial banks declined over the study period. The main cause of the decline in total factory production was due to a reduction in technological efficiency. It is therefore recommended that Pan African Commercial banks substantially upgrade technology. Moreover, there is an increase in the technical efficiency of Pan African Commercial Banks over the study period. On average the technical efficiency of the Pan African commercial banks is largely contributed by the scale efficiency than pure technical efficiency. Therefore, Pan African Commercial banks should enhance managerial efficiency.
\end{abstract}

Keywords: Data Envelopment Analysis (DEA), Malmquist Index, Technical Efficiency, Pure Technical Efficiency, Scale Efficiency, Pan African Banks.

\section{Introduction}

In any economy, the financial sector is the engine that drives economic growth through efficient allocation of resources to productive units. Banking efficiency is a precondition for economic growth and important for the effectiveness of monetary policy (Hartmann, 2004). Literature gives evidence of financial sector development being a predictor of: future economic growth rate; accumulation of capital; and change in technology (Levine, 1997). Financial sector development is imperative for economic growth and it can be achieved through improved efficiency in financial sector institutions. Banking sector efficiency is important for promoting access to financial services as well as the stability of the banking sector as an integral component of the financial system. Banks play an essential role in the proper functioning of payments systems and their efficiency is directly related to improved productivity in the economy (Ikhide, 2009).

The banking sector in sub-Saharan Africa has expanded steadily over the past decade. Beck and Cull (2013) noted that banking in SSA has undergone dramatic changes over the past 20 years. Financial liberalization and related reforms, upgrades in institutional and regulatory capacity, and more 
INTERNATIONAL JOURNAL OF ACADEMIC RESEARCH IN BUSINESS AND SOCIAL SCIENCES Vol. 10, No. 8, 2020, E-ISSN: 2222-6990 @ 2020 HRMARS

recently the expansion of cross-border banking activities with the rapid development of pan-African banking groups' networks have significantly changed the African banking and financial landscape. Once dominated by state-owned institutions and distorted in their operations by restrictive regulations, banking systems in SSA are now deeper and more stable, the incidence of systemic banking crises has declined dramatically in the last two decades. In fact, banking systems in SSA survived the turmoil of the global financial crisis relatively unscathed, despite indirect pressures through international trade linkages.

Another major change in the African banking landscape in recent years has been the emergence and rapid expansion of pan-African banking groups (PABs). These banks have created significant crossborder networks and are in some respects taking over the role of the European and US banks that traditionally dominated banking activities in SSA. According to Beck et al (2014) foreign banks operating in Africa comprise two distinct groups; international banks domiciled outside of Africa and African cross-border banks (Pan African Banks). During recent years, cross-border Africa-based banks, once largely domestic, are expanding across the continent and now dominate the banking sector in many countries. These so-called pan-African banks are establishing cross-border networks and overtaking the European and U.S. banks, which traditionally dominated banking on the continent. The new pan-African players are driving the expansion of financial services and economic integration in Africa, helping unlock the huge potential of a fast-growing region (Mathieu, 2015).

Pan-African banking groups have expanded rapidly across sub-Saharan Africa (SSA). There are various reasons for the expansion of pan-African banks (PABs), although two factors in particular played an important role in this regard. Firstly, as domestic markets become saturated, banks are often forced to look beyond borders for potential growth opportunities. Secondly, regulatory changes in the country where banks are domiciled could also influence ambitions to expand beyond borders(KPMG, 2015). The economies of both host and home countries receive numerous benefits from the expansion of cross-border banking. The rise of pan-African banks has increased competition and efficiency, introduced product innovation and more modern management and information systems, and brought higher skills and expertise to host banking sectors. Several pan-African banks have exported innovative business models and delivery channels, such as mobile banking by Kenyan institutions, to host countries. These advances have helped expand the availability of banking services and products (Mathieu, 2015). These banks originate mainly in the largest economies of Africa, such as South Africa, Nigeria, and Morocco, and from countries of influence within a region, such as Kenya. But one of the major pan-African institutions, Ecobank, is headquartered in tiny Togo.

This study sought to assess the technical efficiency of commercial banks in Sub Saharan Africa by comparing the pan African banks with domestic banks and foreign banks. There technical efficiencies of these banks are measured using Malmquist Data Envelopment Analysis Methods. Technical efficiency is the ability to produce as much output as the input resources allow; or the ability to use as little input as the production output allows, essentially it is the reduction of wastage in production (Fried et al., 1993). Efficiency in general is a measure of deviation between actual performance and desired performance; efficiency can, therefore, be defined in terms of orientation, i.e., as an inputoriented as well as an output-oriented measure of efficiency. An output-oriented measure of efficiency compares the observed output with maximum output possible for a given input level; alternatively, an input-oriented measure of efficiency compares the observed level of input with the minimum input that could produce the observed level of output (Raphael, 2012). 
INTERNATIONAL JOURNAL OF ACADEMIC RESEARCH IN BUSINESS AND SOCIAL SCIENCES Vol. 10, No. 8, 2020, E-ISSN: 2222-6990 @ 2020 HRMARS

Efficiency comparisons between foreign and domestic banks in developing countries yield very different results. Apart from that cross country comparisons of bank efficiency is lacking in the literature. Even the comparison is always between the domestic bank and the foreign bank. Pan African banks are not taken in to account. Empirical evidence clearly shows that studies focusing on Sub-Saharan Africa's commercial banking sector are still scanty and limited. A few studies on SSA commercial banking are more of country-specific and don't provide comparative information across countries. A few studies on SSA have used data only drawn from single-country studies or smaller sub-regions like West Africa, North Africa, and the Middle East and East Africa. The conclusions from these studies may not be objectively relied on to inform policy on the entire SSA banking system(Francis, 2013).

Therefore, this study tries to fill this gap by measuring the technical efficiency of commercial banks in Sub Saharan Africa by comparing the pan African banks with domestic banks and foreign banks using Malmquist Data Envelopment Analysis Methods over the period 2010-2015. To the best knowledge of the researcher, prior studies have not reported on efficiency analysis of Sub Saharan Africa countries commercial banks during 2010-2015. Hence, this paper will have a significant contribution to policymakers, academics, bank regulators as well as management studying trends in commercial bank efficiency. Secondly, this paper will provide an indication of success or failure by which the performance of individual banks and the industry in general can be measured. Moreover, the results of this study would provide explicit indications as to whether the Pan African banks are efficient than domestic and foreign banks.

The remainder of the paper is organized as follows. Section two presents an overview of Pan African Banks. Section three describes the method and data used in the study. Section four presents results and discussion. Finally, conclusions and recommendations are presented in section five.

\section{Literature Review}

Different studies in different periods are conducted on the efficiency of commercial banks. For instance, Aikaeli (2006) examines the Commercial Banks technical Efficiency in Tanzania. Applying data envelopment analysis on the Input variables (labor, capital, and deposits) and Output variables (loans, advances, and overdrafts) the study showed that the technical efficiency of commercial banks in Tanzania is found to be fairly high. In terms of technical efficiency score, foreign banks ranked the highest, followed by small banks and then large domestic banks; while regarding scale efficiency, small banks ranked the highest followed by international banks and then large domestic banks. Evidences from the findings indicate that $x$-inefficiency in banks was the outcome of inadequate fixed capital, poor labor compensation, less management capacity as banks expanded, and the overwhelming accumulation of excess liquid assets.

Ncube (2009) examined the Efficiency of the Banking Sector in South Africa over the period from 2000 to 2005. In the study, stochastic frontier approach is employed on the Input variables (labor, capital, and other operating costs) and Output variables (loans or total balance of deposits). Doing so, the study indicated that South African banks have significantly improved their cost efficiencies between 2000 and 2005 while; Efficiency gains on profitability over the same time period have not been significant. On the other hand it is shown that No bank was found to be superior to another in terms of achieving efficiency gains in cost reduction and profitability.

Onour and Abdalla (2010) analyzed the Efficiency of Islamic Banks in Sudan using A Non-Parametric Approach. To do so, Salaries, wages and deposits are used as input variables while, Loans and net 
INTERNATIONAL JOURNAL OF ACADEMIC RESEARCH IN BUSINESS AND SOCIAL SCIENCES Vol. 10, No. 8, 2020, E-ISSN: 2222-6990 @ 2020 HRMARS

incomes as output variables. Analyzing the issue of interest Onour and Abdalla (2010) indicated that large banks are both pure technical and scale efficient while Small banks are technical efficient but not scale efficient. As a means to improve efficiency of banks the study recommended that Banks should clean up their nonperforming loan which is in line with provisions and policies adopted by the banks.

Obafemi (2012) examined the technical Efficiency of Nigerian Banks over the period 1984/1985, 1994/1995, 1999/2000, and 2003/2004. Employing data envelopment analysis on Input variables (labor, capital and purchased funds) and Output variables (Loans and advances (demand deposits), time and savings deposits) the study has shown that some banks had their efficiency scores continuously on the increase, others had theirs on the decrease continuously; while a third group had fluctuating efficiency scores. As to the study privately owned banks tend to be more efficient than the publicly-owned banks. On the other hand, big banks like First Bank and Union bank showed higher levels of efficiency than the smaller banks. The percentage of the efficient banks was on the decline within the periods of study and output loss and underutilization of resources among Nigerian banks have been observed.

Raphael (2012) investigated the Commercial Banks efficiency in Tanzania using A non-parametric approach; data envelopment analysis over the period from 2008 to 2011. To undertake a study on the issue of interest, Raphael (2012) used Input variables (Deposit, interest expenses and operating expenses) and Output variables (loan, investment, interest income and no interest income. The analysis result proved that most commercial banks in Tanzania still have a chance of improvement. In terms of size large banks have shown better performance compared to the counterpart small banks. As to the study, to improve technical efficiency Commercial banks should minimize the use of input resources while maintaining the same level of output.

Sangeetha and Jain (2013) studied the technical efficiency of public sector banks in India using data envelopment analysis using Interest expense and Operating expense as input variables and Interest income and other income as output variables. Doing so, the study showed that Corporation Bank, State Bank of India and IDBI were consistently performed efficiently in all the years under study. On the other hand around $40 \%$ to $50 \%$ of public sector banks were performed below the mean score during the study period implying possibility of performance improvement. The study recommended that the efficient banks could be used as a reference or base by other banks to adjust their input use and improve efficiency

Raphael (2013) studied the Efficiency of Commercial Banks in East Africa (Tanzania, Kenya, Uganda, Rwanda and Burundi; Ethiopian being excluded) using A Non-Parametric Approach; data envelopment analysis over the period from 2008 to 2011. Employing DEA on Input variables (capital and labor) and Output variables (deposits and loan accounts) the study indicated that; the banks recorded a sharp decline of Technical efficiency from 0.81 (2008) to 0.56 (2009) thereafter showing an increasing trend of technical efficiency in 0.73 (2011). It is also shown that most commercial banks in east Africa are operating under a decreasing return to scale. To improve efficiency the study recommended commercial banks to minimize the use of input resources while maintaining the same level of output. By improving the handling of operating expenses, advances, capital, and by boosting banking investment operation, the less efficient banks can successfully endorse resource utilization efficiency.

Erasmus and Makina (2014) studied the efficiency of banks in South Africa over the period 2006 to 2012. Employing the Standard and Alternative Approaches to Data Envelopment Analysis (DEA) on 
INTERNATIONAL JOURNAL OF ACADEMIC RESEARCH IN BUSINESS AND SOCIAL SCIENCES Vol. 10, No. 8, 2020, E-ISSN: 2222-6990 @ 2020 HRMARS

Input variables (Deposits, Other liabilities, Shareholders' equity, Staff costs, Non-interest expense and fixed assets) and Output variables (Loans and Overdrafts and Non-interest income) the study showed that under both approaches the majority of the South African banks were observed to be DEA efficient. Such differing results might be due to the fact that; the different variables employed, the different countries under study, the difference in years of study, and different model employed.

Kiyota(2011) has conducted the comparative analysis of cost and profit efficiency of domestic and foreign banks operating in 29 SSA countries by bank ownership (domestic bank, SSA foreign bank, or non-SSA foreign bank) during 2000-07. The result shows that foreign banks tend to perform better than domestic banks for profit efficiency and that foreign bank entry appears to have an impact on improving the performance of domestic banks. The study further revealed that especially as SSA foreign banks seem to be more profit efficient than non-SSA foreign banks - suggest that accelerating the entry of SSA foreign banks (rather than enhancing the entry of non-SSA foreign banks) into SSA host countries may contribute to not only financial sector development there, but may also contribute to private sector development and economic development.

Claessens et al. (2001) find that foreign bank entry is negatively associated with domestic banks' net interest margins and overhead costs, and thus enhances the efficiency of the domestic banking market. In contrast, Hermes and Lensink (2002) find a positive relationship between foreign bank e ntry and domestic banks' margins in low-

income countries. The authors argue that foreign banks crowd out domestic banks, which then ente $r$ other market segments where they subsequently increase their net interest margins through great er market power. Domestic banks' costs increase in the short term as they adopt the costly modern technologies of foreign entrants.

Cho (1985) in theories of multinational banks posits that the foreign subsidiaries of MNBs have technological advantages( broadly defined as product process and distribution technology, management and marketing skills) over domestic banks in developing countries. These advantages allow them to outweigh the costs associated with institutional and cultural differences as well as spatial distance and consumer preferences in foreign markets (Hymer 1976). Thus, generally, foreign banks operate at higher levels of efficiency compared to domestic banks and may force the latter to become more efficient to retain their market shares.

Distinguishing between foreign banks headquartered in industrialized countries and foreign banks $\mathrm{fr}$ om developing countries, Petrou (2007) argues that these types of banks differ from each other wit $h$ regard to their levels of capability: According to the author, foreign banks from industrialized cou ntries have the capital, reputation, modern practices and technologies to enter foreign markets according to risk- diversification and profit opportunities. In contrast, foreign banks from developing countries have fewer resources and skill sets and therefore tend to follow clients from their country. Depending on their competitive advantages, foreign banks from industrialized and developing countries may serve different market segments. Industrialized country banks may mainly exploit the ir advantages in serving low-risk and profitable customers - such as large, exportoriented companies or multinational corporations. But they may lack the necessary soft informa tion and relationship lending techniques for financing less transparent small- and mediumsized enterprises (SMEs), and their mechanical rules and procedures established in more advanced environments (Honohan/Beck 2007) may not be appropriate. Foreign banks from developing count ries may be restricted to serving particular market niches in which they are best equipped with pro prietary client information, expertise and reputation. 
INTERNATIONAL JOURNAL OF ACADEMIC RESEARCH IN BUSINESS AND SOCIAL SCIENCES Vol. 10, No. 8, 2020, E-ISSN: 2222-6990 @ 2020 HRMARS

\section{Methodology}

This study employed Malmquist Data Envelopment Analysis methods to analyze the efficiency of Pan African Commercial Banks. Data envelopment analysis (DEA) is the non-parametric mathematical programming approach to frontier estimation. The pioneer work of the linear programming technique for DEA was developed by Charnes, Cooper and Rhodes (1978).DEA involves the use of linear programming methods to construct a non parametric piece wise surface (or frontier) over the data efficiency measures are then calculated relative to this surface(Timothy J. Coelli, D.S. Prasada Rao, 2005).Under the DEA approach, a best practice frontier which represents optimal utilization level of resources is prepared and efficiency of banks is measured relative to that best frontier (bench mark). If a bank lies on the frontier, it is referred to as an efficient bank otherwise it is termed as less efficient bank. More away the bank is from the frontier, the less efficient it is. Since, in practice, the true ideal technology is not observable, the DEA analysis attempts to define the feasible technology frontier (Harjinder Singh, 2014).

The Malmquist total factor productivity index was first introduced by Malmquist (1953). It is used to measure the change in productivity over time. It is widely been used to measure productivity change in financial sectors. When the Malmquist productivity index (MPI) value is larger than 1, the total factor productivity of the sample improved during the period. Otherwise, the total factor productivity regressed. Technical efficiency change reflecting the catchup effects, measure whether the enterprises are getting closer to the production frontier over time. Technology change reflecting the frontier shift or innovation (Cooperetal, 2007), measures whether the production frontier is moving outward over time. Pure technical efficiency change refers to the management and technical efficiency of the sample. Scale efficiency change refers to the ability of enterprise to work at its optimal Scale.

Malmquist productivity index MPI is used as an output-oriented measure of change in total factor productivity, dealing with the issue of maximizing output while keeping the input quantities as constant. The Malmquist index decomposes this productivity change into two components: The first one is called 'catch-up'. This captures the change in technical efficiency over time. The second one is called 'frontier-shift'. This captures the change in technology which occurs over time (i.e. the movement of efficiency frontiers over time). Technical efficiency is further decomposed into scale efficiency (improvement towards optimal size) and pure efficiency change (improvement in management net of size).

This study implements the output-based MPI. The output-oriented Malmquist index is generally computed as a geometric mean of adjacent year's index values (Fare et al., 1994; Price and WeymanJones, 1996):

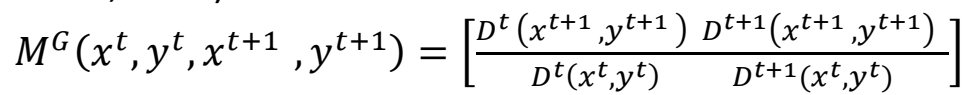

Where $D^{t}(x, y)$ is the distance function value relating observed inputs $x \in R^{K}$ and outputs $y \in$ $R^{m}$ to the production possibilities set corresponding to period t. Conventional claims justifying the index assert $M^{G}$ will be greater than, equal to, or less than 1 depending upon whether productivity change between periods $t$ and $t+1$ is positive, zero, or negative, respectively.

The Malmquist index can be rearranged to isolate productivity changes resulting from changes in efficiency from those technical changes resulting from shifts in the empirical production possibilities frontier (Fare et al., 1994):

Efficiency change: $\left[\frac{D^{t+1}\left(x^{t+1}, y^{t+1}\right)}{D^{t}\left(x^{t}, y^{t}\right)}\right]$ 
INTERNATIONAL JOURNAL OF ACADEMIC RESEARCH IN BUSINESS AND SOCIAL SCIENCES Vol. 10, No. 8, 2020, E-ISSN: 2222-6990 @ 2020 HRMARS

Technical change: $\frac{D^{t}\left(x^{t+1}, y^{t+1}\right) D^{t}\left(x^{t}, y^{t}\right)}{D^{t+1}\left(x^{t+1}, y^{t+1}\right) D^{t+1}\left(x^{t}, y^{t}\right)}$

$M^{G}$ is the product of the efficiency and technical change measures. Efficiency change, or EFFCH, can be further decomposed into pure efficiency gains $\mathrm{PEFFCH}$, and efficiency gains resulting from changes in scale, $\mathrm{SCH}$, or EFFCH = PEFFCH' SCH (Fa“re et al., 1994). Solving the efficiency measure EFFCH and dividing by $\mathrm{PEFFCH}$ isolates productivity changes resulting from changes in scale. In contrast, the distance function values composing the technical change measure are aggregated measures of both scale and efficiency effects.

\section{Constant Returns to Scale and Variable Returns to Scale}

Charnes et al. (1978) propose a model assuming constant returns to scale (CRS model). It is appropriate when all firms operate at the optimal scale. Imperfect competition, constraints on finance, etc. may cause a DMU to be not operating at optimal scale. Efficiency is defined by Charnes et al. $(1978$, p. 430) as the maximum of the ratio of weighted output to weighted inputs subject that the similar ration for every DMU be less or equal to unity. Banker et al. (1984) propose a model assuming variable returns to scale (VRS). It is appropriate when all firms do not operate at optimal scale, will result in measures of TE which are confounded by scale efficiencies (SE). The use of the VRS specification permits the calculation of TE devoid of these SE effects.

\section{Input and Output Specifications}

Two main approaches to defining inputs and outputs in banking are used, namely the intermediation and the production approach. The production approach addresses physical inputs, such as capital and labor and treats a bank as firms producing different deposits and loan accounts. Banks deal with transactions and documents for its customers who own these accounts. The number of accounts and transactions are regarded as the best measures of the bank output; to some extent this is not practical. In practice, the number of deposit and loan account is usually used as the measure of bank output rather than the detailed in transaction and documents (Ferrier and Lovell, 1990). While intermediation approach treats banks as financial intermediaries that channels funds between depositors and creditors in the bank production process, the value of bank loans and investment is thought as output, while labor, deposits, and capital are treated as inputs(Sealey and Lindley, 1997). In this study the researcher applied intermediation approach which includes Deposit, interest expenses, operating expenses as input and loan, investment, interest income and noninterest income as output. This selection of input and output was also supported by (Raphael, 2012; Miller and Noulas 1996; Hassan, et al 2009; Singh, et al 2008; Siems, 1992; Yue, 1992; Barr, R.S., L. M. Seaford and Siems, 1993). Moreover, Input-orientated technical efficiency measures and output-orientated measures are presented. Input-orientated measures address the question by how much can input quantities is proportionally reduced without changing the output quantities produced. Output-orientated measures address the question by how much can output quantities is proportionally expanded without altering the input quantities used (Coelli et al., 1998:137). In this study, the researcher used output orientation when running Malmquist DEA methods under Constant Return to Scale (CRS) assumptions. 
INTERNATIONAL JOURNAL OF ACADEMIC RESEARCH IN BUSINESS AND SOCIAL SCIENCES Vol. 10, No. 8, 2020, E-ISSN: 2222-6990 @ 2020 HRMARS

\section{Data}

The data used in this paper were obtained from the Bank Scope database for the period 2010 to 2015. The latest issue of bank scope database used in this study was February 2016. Major Pan African Commercial Banks are included in this study such as Ecobank, Standard Bank, United Bank For Africa, Attijariwafa Bank, Banque Marocaine Du Commerce Exterieur-BMCE, and Kenyan Commercial Bank. Due to the lack of a single accounting standard across the continent, only banks applied IFRS selected in this study. Hence, banks that were applied local GAAP are not considered. DEAP version 2.1 of DEA computer program developed by Tim Coelli has been used to calculate the efficiency of the banks in the data set.

\section{Results and Discussion}

The change in total factor productivity (tfpch) can be attributed either to an efficiency change (Effch) or technological change (techch) or even both. An efficiency change is further associated with a change in pure efficiency (Pech) or scale efficiency change (Sech) or both. Table one summarizes the results of geometric mean efficiency changes in the period 2010-2015. As shown in the table, the mean geometric MPI values were 0.491in 2010-2011, 0.713 in 2011-2012, 1.215 in 2012-2013, 0.907 in 2013-2014 and 1.325 in 2014 to 2015.

The average level of the Malmquist index (tfpch) was only 0.875 , meaning that there was a decline in TFP by 12.5 percent over the study period, despite the mean score of the technical efficiency index (effch) of 1.122. This means, the technical efficiency change supported the average growth in productivity by 12.2 percent compared to the technological change. The main cause for the decline in TFP was due to a 22 percent reduction in technological efficiency. Technological change was a major source of productivity decline over the study periods.

As it is depicted in table 1, in 2010-2011 and 2011-2012 the total factor productivity change is less than one because of the technological change index was a major source of productivity decline. Pan African Commercial banks need to substantially upgrade technology to reverse this. In 2012-2013 TFP increases by around 50.2 percent as a result of an increase in technological change (70.5 percent). In the next year, which means 2013-2014 TFP decreased by 30.8 percent as a result of the decrease in technological change (35.2 percent). In 2014- 2015 TFP increased by 41.8 percent as a result of an increase in both technical efficiency change (7.5 percent) and technological change (32.8 percent). The average technical efficiency change was 1.122 meaning that there is an increase in the technical efficiency of Pan African Commercial Banks by 12.2 percent over the study periods. This is because of an increase of pure technical efficiency by 2.2 percent and scale efficiency by 9.8 percent over the study period. During the first years of the study (2010 to 2013), the technical efficiency changes have declined by 44 percent then after an increase of 10.6 percent.

As it is observed from table two regarding productivity changes in individual banks; all banks technical efficiency change was more than one meaning that they are technically efficiency; however the total factor productivity change of Ecobank Kenya Limited, Standard Bank Mauritius Limited, United Bank for Africa PLC, Attijariwafa Bank Morocco, and KCB Group limited was less than one because of an average decline of 22 percent of technology change.

United Bank for Africa PLC and Ecobank Kenya Limited has observed the least total factor productivity change due to technological regress. The total factor productivity change of the Ecobank Zimbabwe Limited and Malawi Standard Bank Limited are greater than one due to a substantial technical 
INTERNATIONAL JOURNAL OF ACADEMIC RESEARCH IN BUSINESS AND SOCIAL SCIENCES Vol. 10, No. 8, 2020, E-ISSN: 2222-6990 @ 2020 HRMARS

efficiency change. While the total factor productivity change of CFC Stanbic Bank and BMCE is greater than one; predominantly due to an improvement of technological efficiency. The maximum technical efficiency score observed in Malawi Standard Bank Limited, KCB Group limited and Ecobank Zimbabwe Limited was 1.436, 1.425, and 1.373 respectively. These banks' technical efficiency change is further decomposed into pure technical efficiency change that measures performance only due to managerial activity and scale efficiency change and both these indices are positive meaning improved productivity. Therefore, the maximum technical efficiency of the Malawi Standard Bank Limited is due to both the improvement in pure technical efficiency by 20.2 percent and scale efficiency by 19.5 percent; Ecobank Zimbabwe Limited is because of both pure technical efficiency and scale efficiency by 4 percent and 32 percent respectively. Whereas KCB Group Limited is only because of an increase of scale efficiency by 46.7 percent. The technical efficiency change of the remaining banks is because of equal change in both pure technical efficiency and scale efficiency. On average the technical efficiency of the Pan African commercial banks is largely contributed by the scale efficiency by 9.8 percent. Whereas, pure technical efficiency is contributing 2.2 percent to the technical efficiency. Kenyan Commercial Bank scores the lowest pure technical efficiency change.

Table 2: Malmquist Index Summary of Annual Means

\begin{tabular}{llllll}
\hline Year & Effch & Techch & Pech & Sech & Tfpch \\
\hline $2010-2011$ & 1.400 & 0.351 & 0.925 & 1.513 & 0.491 \\
$2011-2012$ & 1.262 & 0.565 & 1.200 & 1.051 & 0.713 \\
$2012-2013$ & 0.957 & 1.270 & 1.010 & 0.948 & 1.215 \\
$2013-2014$ & 0.988 & 0.918 & 0.959 & 1.030 & 0.907 \\
$2014-2015$ & 1.063 & 1.246 & 1.037 & 1.026 & 1.325 \\
Mean & 1.122 & 0.780 & 1.022 & 1.098 & 0.875 \\
& & & & & \\
\hline
\end{tabular}

Note: effch = technical efficiency change; techch = technology change; pech = pure technical efficiency change; sech = scale efficiency change; and tfpch = total factor productivity change

Table 3: Malmquist Index Summary of Firm Means 
INTERNATIONAL JOURNAL OF ACADEMIC RESEARCH IN BUSINESS AND SOCIAL SCIENCES Vol. 10, No. 8, 2020, E-ISSN: 2222-6990 @ 2020 HRMARS

\begin{tabular}{llllllll}
\hline Country & Pan African Banks & Banks & Effch & Techch & pech & sech & Tfpch \\
\hline Kenya & Ecobank & $\begin{array}{l}\text { Ecobank Kenya } \\
\text { Limited }\end{array}$ & 1.000 & 0.604 & 1.000 & 1.000 & 0.604 \\
Zimbabwe & Ecobank & $\begin{array}{l}\text { Ecobank } \\
\text { Zimbabwe Limited }\end{array}$ & 1.373 & 0.753 & 1.040 & 1.320 & 1.034 \\
$\begin{array}{l}\text { Mauriti } \\
\text { us }\end{array}$ & Standard Bank & $\begin{array}{l}\text { Standard Bank } \\
\text { Mauritius Limited }\end{array}$ & 1.000 & 0.913 & 1.000 & 1.000 & 0.913 \\
$\begin{array}{l}\text { Kenya } \\
\text { Malawi }\end{array}$ & $\begin{array}{l}\text { Standard Bank } \\
\text { Standard Bank }\end{array}$ & $\begin{array}{l}\text { Standard Bank } \\
\text { Limited }\end{array}$ & 1.436 & 0.818 & 1.202 & 1.195 & 1.175 \\
Nigeria & United bankfor Africa & $\begin{array}{l}\text { United bankfor } \\
\text { Africa Plc }\end{array}$ & 1.000 & 0.425 & 1.000 & 1.000 & 0.425 \\
Morocco & Attijariwafa Bank & Attijariwafa Bank & 1.000 & 0.913 & 1.000 & 1.000 & 0.913 \\
Morocco & $\begin{array}{l}\text { Banqu Marocaine Du } \\
\text { Commerce Exterieur- }\end{array}$ & BMCE & 1.000 & 1.291 & 1.000 & 1.000 & 1.291 \\
Bmce & Kenyan Commercial Bank & $\begin{array}{l}\text { KCB Group } \\
\text { limited }\end{array}$ & 1.425 & 0.610 & 0.971 & 1.467 & 0.868 \\
Kenya & & 1.122 & 0.780 & 1.022 & 1.098 & 0.875 \\
\hline Geometric & Mean & & & & 1.000 & 1.000 \\
\hline
\end{tabular}

Note: effch = technical efficiency change; techch = technology change; pech = pure technical efficiency change; sech = scale efficiency change; and tfpch = total factor productivity chang

\section{Conclusion and Recommendations}

The results reveal that the total factor productivity of Pan African Commercial banks decline over the study period. The main cause of the decline of total factor production was a reduction in technological efficiency. Therefore, Pan African Commercial banks called to substantially upgrade technology and should focus on introducing new technologies that may cause a positive shift in the production frontier.

There is an increase in the technical efficiency of Pan African Commercial Banks over the study periods. This was due to pure technical efficiency improvement realized by adopting correct managerial decisions and scale efficiency obtained by getting closer to the optimum size. Therefore, these banks should pursue better management practices and their scale efficiency by realizing economies of scale. On average the technical efficiency of the Pan African commercial banks is largely contributed by the scale efficiency than pure technical efficiency. Therefore, Pan African Commercial banks should enhance managerial efficiency.

Least total factor productivity change observed at the united bank for Africa PLC and Ecobank Kenya Limited due to technological regress. Thus, United Bank for Africa PLC and Ecobank Kenya Limited urgently called for technological improvement. In contrast, Kenyan Commercial Bank scores the lowest pure technical efficiency change. Therefore, Kenyan Commercial Bank suggested to improve the management system.

\section{Scope for Further Study}

The lack of a single accounting standard across the continent makes the sample size small and a comparison of the efficiency of the small bank against large Banks (the association between the size of banks and productivity) is not considered in the analysis. Future research should address this issue. To the best of researcher knowledge except IMF staff team led by Charles Enoch, Paul Mathieu and 
INTERNATIONAL JOURNAL OF ACADEMIC RESEARCH IN BUSINESS AND SOCIAL SCIENCES Vol. 10, No. 8, 2020, E-ISSN: 2222-6990 @ 2020 HRMARS

Mauro Mecagni entitled Pan African Banks opportunities and challenges for crossborder oversight; no studies have been done regarding Pan African Commercial Banks. Therefore, it will require more studies by taking this research as a starting point. Furthermore,

Future research should be concerned with a comparison of pan African commercial banks against domestic Banks and Foreign Banks.

\section{References}

Almumani, M. A. (2013). The Relative Efficiency of Saudi Banks : Data Envelopment Analysis Models, 3(3), 152-161. http://doi.org/10.6007/IJARAFMS/v3-i3/115.

Barr, R. S., Seiford, L. M., \& Siems, T. F. (1993). An Envelopment analytical approach to measuring the managerial efficiency of banks. Third European Workshop on efficiency and productivity measurement,www.ccsenet.org/ijbm International Journal of Business and Management Vol. 8, No. 4; 2013 center for operational research and econometric, Louvain, Belgium (October).

Charnes, C., and Rhodes. (1978). Measuring the Efficiency of Decision Making Units. European Journal of Operational Research. 2 (4). 429-444.

Coelli, T., Rao, P. D. S., and Battese, G. E. (1998). An Introduction to Efficiency and Productivity Analysis, Springer, Berlin

Coelli, T. (2008). A Guide to DEAP Version 2 . 1 : A Data Envelopment Analysis (Computer) Program by (No. 96/08). Australia.

Cooper, W. W., Seiford, L. M., and Kaoru, T. (2007).Dataenvelopmentanalysis, AComprehensive TextwithModels, Applications, Referencesand DEA-SolverSoftware,Springer,NewYork, NY.

Debreu. (1951). The coefficient of http://dx.doi.org/10.2307/1906814 resource utilization. Econometrica, 273-92.

Ecobank. (2016). reference. Retrieved from http://www.ecobank.com/group/ecobanktoday

Erasmus, C., \& Makina, D. (2014). 'An Empirical Study of Bank Efficiency in South Africa Using the Standard and Alternative Approaches to Data Envelopment Analysis (DEA)'. Journal of Economics and Behavioral Studies, 6(4), 310-317.

Farrell, M. J. (1957). The measurement of productive efficiency. Journal of royal statistical society series, 253-81. http://dx.doi.org/10.2307/2343100

Ferrier, G., \& Lovell, C. A. K. (1990). Measuring cost efficiency in banking: Econometric and linear programming evidence. Journal of Econometrics, 46, 229-245. http://dx.doi.org/10.1016/0304-4076(90)90057-Z

Hassan, T. (2009). Efficiency of convectional versus from Islamic banks: Evidence from Middle East.International Journal of Islamic and Middle Eastern Finance Management, 2(1), 46- 65. http://dx.doi.org/10.1108/17538390910946267

Ikhide, S. I. (2008). Measuring the operational efficiency of commercial banks in Namibiall, South African Journal of Economics. Vol. 76, no. 4, pp. 586 - 95.

Koopmans, T. (1951). Activity analysis of Production and allocation. John Wiley \& Sons, Newyork. KPMG. (2015). Banking in Sub-Saharan Africa.

Malmquist, S. (1953). Index numbers and indifference surfaces, Trabajos de Estadística y de Investigación Operativa, Vol. 4 No. 2, pp. 209-242.

Mathieu, A. B. P. (2015). Continental Reach. Finance \& Development, 52, No. 2(June).

Miller, S., and Noulas. (1996). The technical efficiency of Large Banks Production, Journal of Banking and Finance ,20,3,495-509. 
INTERNATIONAL JOURNAL OF ACADEMIC RESEARCH IN BUSINESS AND SOCIAL SCIENCES

Vol. 10, No. 8, 2020, E-ISSN: 2222-6990 @ 2020 HRMARS

Obafemi, F. N. (2012). The technical efficiency of Nigerian banks. Asian Economic and Financial Review, 2(2), 407.

Onour, I. A., \& Abdalla, A. M. (2010). Efficiency of Islamic banks in Sudan: a non-parametric approach. API/WPS, 1012.

Raphael, G. (2012). Commercial banks efficiency in Tanzania : A non parametric approach. European Journal of Business and Management, 4(21), 55-68. http://doi.org/10.5539/ijbm.v8n4p50.

Raphael, G. (2013). Efficiency of Commercial Banks in East Africa: A Non Parametric Approach. International Journal of Business and Management,8(4), p50.

Samy, B. N., Hichen, B. K., \& Barbara, C. (2009). What drives efficiency of selected MENA banks? A Meta frontier analysis WP03/09 Cass business school.

Sealey, C., \& Lindley, J. (1997). Inputs and outputs, and Theory of production and cost at depository financial institutions. Journal of finance, 32(4).

Siems, T. F. (1992). Quantifying Management`s role in bank survival. Federal Reserve bank of Dallas, Economic Review (January), 29-41.

Singh. (2008). A Cross country comparison of banking efficiency: Asian Pacific Banks. International Review of business research papers, 4(3), 73-95.

Siudek, T. (2008). Theoretical foundation of banks' efficiency and empirical evidence from Poland., 3 (3), 150-158.

Yue, P. (1992). Data Envelopment Analysis and Commercial bank performance: A primer with application to Missouri banks. Federal Reserve Bank of St. Louis Review, 74, 31-45. 